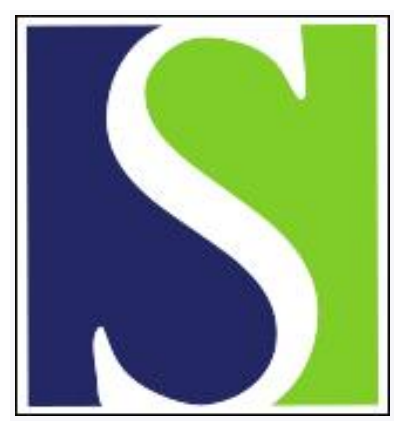

Scand J Work Environ Health 1979;5(4):345-351

https://doi.org/10.5271/sjweh.2647

Issue date: Dec 1979

Comparative percutaneous toxicity of ten industrial solvents in the guinea pig.

by Wahlberg JE, Boman A

Key terms: 1,1,1-trichloroethane; carbonatetrachloride; comparative percutaneous toxicity; dimethylformamide; ethyleneglycolmonobutylether; guinea pig; industrial solvent; intraperitoneal toxicity; n-hexane; percutaneous toxicity; toxicity; trichloroethylene

This article in PubMed: www.ncbi.nlm.nih.gov/pubmed/538425

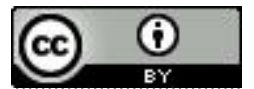




\title{
Comparative percutaneous toxicity of ten industrial solvents in the guinea pig
}

\author{
by JAN E. WAHLBERG, M.D., and ANDERS BOMAN, B.Sc. ${ }^{1}$
}

\begin{abstract}
WAHLBERG, J. E. and BOMAN, A. Comparative percutaneous toxicity of ten industrial solvents in the guinea pig. Scand. j. work environ. \& health 5 (1979) 345-351. This report is part of a study on skin pathology, blood levels and percutaneous toxicity after the epicutaneous administration of solvents. The method used for the study of percutaneous toxicity differentiated between different types of solvents, and between different applied volumes of the same solvent. Five solvents caused some mortalities (in declining order: 2-chloroethanol, 1,1,2-trichloroethane, ethyleneglycolmonobutylether, carbontetrachloride, and dimethylformamide). Four solvents - benzene, toluene, 1,1,1-trichloroethane, and trichloroethylene - did not cause mortality, but a statistically significant effect on weight gain was observed. For $n$-hexane the weight gain did not differ $(\mathrm{P}>0.2)$ from that of the control animals exposed to distilled water. For comparison, the same amounts of the sol. vents were injected intraperitoneally. There was a fairly good agreement between intraperitoneal and percutaneous toxicity, but slight deviations were observed for carbontetrachloride and dimethylformamide.
\end{abstract}

Key words: Carbonatetrachloride, dimethylformamide, ethyleneglycolmonobutylether, guinea pigs, n-hexane, intraperitoneal toxicity, percutaneous toxicity, 1,1,1-trichloroethane, trichloroethylene.

To evaluate toxicity following the epicutaneous application of solvents, one can observe morphological changes in exposed skin $(4,5)$, determine the concentrations in blood, urine and exhaled air $(1,2,3,7,9$, $11,13)$, and register effects such as mortality or impaired weight gain $(6,11,17$, 18). Observed blood levels do not, however, give any conclusive information unless they are related to resulting systemic toxicity. The aim of the present study was

1 Department of Occupational Dermatology, National Board of Occupational Safety and Health and Karolinska sjukhuset, Stockholm, Sweden.

Reprint requests to: Dr. J. Wahlberg, Department of Occupational Dermatology, Karolinska sjukhuset, S-104 01 Stockholm, Sweden. to compare the percutaneous toxicity of six industrial solvents with four previously studied ones $(17,18)$. The method $(14$, $15,17,18)$ has not been used to make $L_{50}$ (median lethal dose) determinations; instead it has enabled a mutual comparison (ranking list) of a number of solvents.

\section{MATERIALS AND METHODS}

The following chemicals were studied: carbontetrachloride (p.a. Merck, Darmstadt, Federal Republic of Germany), dimethylformamide (p.a. Mallinckrodt, St. Louis, U.S.A.), ethyleneglycolmonobutylether (99 \%, Aldrich, Beerse, Belgium), 
n-hexane (p.a. Merck, Darmstadt, Federal Republic of Germany), 1,1,1-trichloroethane (Puriss, p.a., Fluka, Buchs, S.G., Switzerland), trichloroethylene (Puriss, Merck, Darmstadt, Federal Republic of Germany). Distilled water was used as a control.

Details of the method used for studying percutaneous toxicity have been given in previous papers $(14,15,17,18)$. In short, a single application of different amounts $(0.5$ or $2.0 \mathrm{ml})$ of the solvents is administered to a skin depot (area $3.1 \mathrm{~cm}^{2}$ ) which is eventually covered to prevent inhalation and licking. Guinea pigs of the same initial weight $(352-375 \mathrm{~g})$ were used, and it is calculated that $0.7 \%$ of the body area was exposed.

The deposit could be observed through the cover glass, and it was easy to see when all of the material had been absorbed. The depots did not become detached from the animals before the fifth to the seventh day, and by then complete absorption had invariably taken place.

The animals were observed for $35 \mathrm{~d}$ for clinical symptoms and were weighed once daily except on weekends. The times until death were recorded. For comparison the same amounts of the solvents were injected intraperitoneally, and the animals were followed in the same manner as the epicutaneously exposed guinea pigs.

A total of 210 guinea pigs were exposed epicutaneously, and 90 intraperitoneally. They were housed in groups of three in Makrolon cages, fed standard laboratory animal food (Astra Ewos, Södertälje, Sweden) and given ascorbic acid in their drinking water.

An analysis of variance was applied in the statistical calculations.

\section{RESULTS}

The percutaneous toxicity of the solvents has been summarized in tables 1,2 and 4 and fig. $1-3$. As seen in table $1,2.0 \mathrm{ml}$ of both carbontetrachloride and ethyleneglycolmonobutylether caused the highest mortality rates (13 of 20 animals). For ethyleneglycolmonobutylether all 13 animals died within the first week, while for

Table 1. Percutaneous toxicity after the administration of 0.5 or $2.0 \mathrm{ml}$ of six solvents. Twenty guinea pigs were exposed in each series.

\begin{tabular}{|c|c|c|c|c|c|c|c|c|c|c|}
\hline \multirow[b]{2}{*}{ Solvent } & \multirow{2}{*}{$\begin{array}{l}\text { Applied } \\
\text { volume } \\
\text { (ml) }\end{array}$} & \multirow{2}{*}{$\begin{array}{c}\text { Mean } \\
\text { weight } \\
\pm \text { SEMa } \\
\text { (g) }\end{array}$} & \multicolumn{8}{|c|}{ Cumulative mortality rate } \\
\hline & & & $\begin{array}{c}\text { Day } \\
1\end{array}$ & $\begin{array}{c}\text { Day } \\
2\end{array}$ & $\begin{array}{c}\text { Day } \\
3\end{array}$ & $\begin{array}{c}\text { Day } \\
4\end{array}$ & $\underset{7}{\text { Day }}$ & $\begin{array}{c}\text { Day } \\
14\end{array}$ & $\begin{array}{c}\text { Day } \\
21\end{array}$ & $\begin{array}{c}\text { Day } \\
35\end{array}$ \\
\hline $\begin{array}{l}\text { Carbontetra- } \\
\text { chloride }\end{array}$ & $\begin{array}{l}0.5 \\
2.0\end{array}$ & $\begin{array}{l}372 \pm 3 \\
373 \pm 5\end{array}$ & $\begin{array}{l}0 \\
1\end{array}$ & $\begin{array}{l}0 \\
3\end{array}$ & $\begin{array}{l}1 \\
3\end{array}$ & $\begin{array}{l}2 \\
4\end{array}$ & $\begin{array}{l}3 \\
4\end{array}$ & $\begin{array}{r}5 \\
12\end{array}$ & $\begin{array}{r}5 \\
13\end{array}$ & $\begin{array}{r}5 \\
13\end{array}$ \\
\hline $\begin{array}{l}\text { Dimethyl- } \\
\text { formamide }\end{array}$ & $\begin{array}{l}0.5 \\
2.0\end{array}$ & $\begin{array}{l}374 \pm 2 \\
374 \pm 5\end{array}$ & $\begin{array}{l}0 \\
0\end{array}$ & $\begin{array}{l}0 \\
0\end{array}$ & $\begin{array}{l}0 \\
1\end{array}$ & $\begin{array}{r}0 \\
10\end{array}$ & $\begin{array}{r}0 \\
10\end{array}$ & $\begin{array}{r}0 \\
10\end{array}$ & $\begin{array}{r}0 \\
10\end{array}$ & $\begin{array}{r}0 \\
10\end{array}$ \\
\hline $\begin{array}{l}\text { Ethyleneglycol- } \\
\text { monobutylether }\end{array}$ & $\begin{array}{l}0.5 \\
2.0\end{array}$ & $\begin{array}{l}373 \pm 2 \\
374 \pm 4\end{array}$ & $\begin{array}{l}0 \\
0\end{array}$ & $\begin{array}{l}0 \\
0\end{array}$ & $\begin{array}{l}0 \\
5\end{array}$ & $\begin{array}{r}0 \\
11\end{array}$ & $\begin{array}{r}0 \\
13\end{array}$ & $\begin{array}{r}0 \\
13\end{array}$ & $\begin{array}{r}0 \\
13\end{array}$ & $\begin{array}{r}0 \\
13\end{array}$ \\
\hline n-Hexane $(\mathrm{N}=30)$ & 2.0 & $374 \pm 3$ & 0 & 0 & 0 & 0 & 0 & 0 & 0 & 0 \\
\hline $\begin{array}{l}\text { 1,1,1-Trichloro- } \\
\text { ethane }\end{array}$ & 2.0 & $375 \pm 2$ & 0 & 0 & 0 & 0 & 0 & 0 & 0 & 0 \\
\hline $\begin{array}{l}\text { Trichloro- } \\
\text { ethylene }\end{array}$ & 2.0 & $375 \pm 4$ & 0 & 0 & 0 & 0 & 0 & 0 & 0 & 0 \\
\hline Distilled water & 2.0 & $375 \pm 1$ & 0 & 0 & 0 & 0 & 0 & $\mathbf{0}$ & 0 & 0 \\
\hline
\end{tabular}

a Standard error of the mean. 
carbontetrachloride four died within the first week and eight during the second week. For dimethylformamide, 10 guinea pigs died within four days, while for n-hexane, 1,1,1-trichloroethane and trichloroethylene, no mortalities were observed. Decreasing the applied volume from 2.0 to $0.5 \mathrm{ml}$ reduced the number of mortalities to 5 of 20 animals for carbontetrachloride (and the deaths occurred later) and to zero for dimethylformamide and ethyleneglycolmonobutylether.

Table 2 and fig. 1 show the weight increase of the control animals (exposed to $2.0 \mathrm{ml}$ distilled water) and the animals exposed to nonlethal solvent doses. For dimethylformamide $(0.5 \mathrm{ml}), 1,1,1$-trichloroethane $(2.0 \mathrm{ml})$, and trichloroethylene $(2.0 \mathrm{ml})$, the differences from the controls were statistically significant, but a mutual comparison of these three solvents showed no statistically significant difference.

The intraperitoneal toxicity is presented in tables 3 and 5. After an injection of $2.0 \mathrm{ml}$ of the solvents, the mortality rate varied between 80 and $100 \%$. After $72 \mathrm{~h}$ there were no additional mortalities. The mean time to death for the most toxic solvent (ethyleneglycolmonobutylether) was
$49 \mathrm{~min}$. Reducing the volume to $0.5 \mathrm{ml}$ decreased the number of mortalities, and they appeared later.

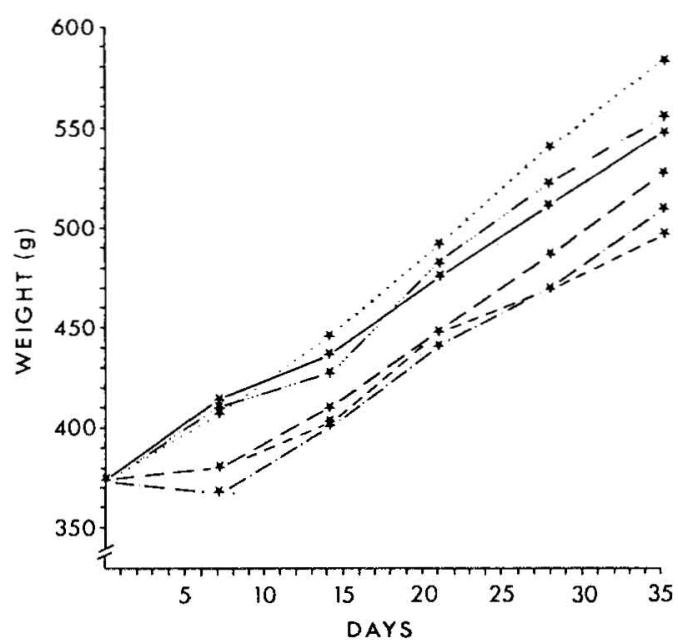

Fig. 1. Mean development of guinea pig weight following percutaneous application of solvent $(0.5$ or $2.0 \mathrm{ml})$ or distilled water (control). No mortality in these series. [ . . ethyleneglycolmonobutylether $(0.5 \mathrm{ml}),-\cdots-\cdots$ hexane $(2.0 \mathrm{ml}) \longrightarrow$ distilled water $(2.0 \mathrm{ml})$, - - trichloroethylene $(2.0 \mathrm{ml}), \ldots$. dimethylformamide $(0.5 \mathrm{ml}),--1,1,1$-trichloroethane $(2.0$ $\mathrm{ml})]$

Table 2. Weight gain after the percutaneous administration of 0.5 or $2.0 \mathrm{ml}$ of five organic solvents. Twenty guinea pigs were exposed in these series (no mortality).

\begin{tabular}{|c|c|c|c|c|c|c|c|}
\hline \multirow{2}{*}{ Solvent } & \multirow{2}{*}{$\begin{array}{l}\text { Applied } \\
\text { volume } \\
\text { (ml) }\end{array}$} & \multicolumn{6}{|c|}{ Mean weight $\pm \operatorname{SEM}{ }^{a}(\mathrm{~g})$} \\
\hline & & Day 0 & Day 7 & Day 14 & Day 21 & Day 28 & Day 35 \\
\hline $\begin{array}{l}\text { Dimethyl- } \\
\text { formamide }\end{array}$ & 0.5 & $374 \pm 2$ & $\begin{array}{l}369 \pm 5 \\
\mathrm{p}<0.001\end{array}$ & $\begin{array}{l}402 \pm 2 \\
\mathrm{p}<0.001\end{array}$ & $\begin{array}{l}442 \pm 5 \\
\mathrm{p}<0.01\end{array}$ & $\begin{array}{l}471 \pm 6 \\
\mathrm{p}<0.001\end{array}$ & $\begin{array}{l}510 \pm 5 \\
\mathrm{p}<0.01\end{array}$ \\
\hline $\begin{array}{l}\text { Ethyleneglycol- } \\
\text { monobutylether }\end{array}$ & 0.5 & $373 \pm 2$ & $\begin{array}{l}408 \pm 3 \\
0.2<p\end{array}$ & $\begin{array}{l}446 \pm 4 \\
0.2<p\end{array}$ & $\begin{array}{l}492 \pm 6 \\
0.05<p\end{array}$ & $\begin{array}{l}540 \pm 7 \\
\mathrm{p}<0.01\end{array}$ & $\begin{array}{l}580 \pm 7 \\
\mathrm{p}<0.01\end{array}$ \\
\hline $\mathrm{n}$-Hexane $(\mathrm{n}=30)$ & 2.0 & $374 \pm 3$ & $\begin{array}{l}410 \pm 4 \\
0.2<p\end{array}$ & $\begin{array}{l}427 \pm 6 \\
0.2<p\end{array}$ & $\begin{array}{l}485 \pm 5 \\
0.2<p\end{array}$ & $\begin{array}{l}523 \pm 6 \\
0.2<p\end{array}$ & $\begin{array}{l}554 \pm 6 \\
0.2<p\end{array}$ \\
\hline $\begin{array}{l}\text { 1,1,1-Trichloro- } \\
\text { ethane }\end{array}$ & 2.0 & $375 \pm 2$ & $\begin{array}{l}380 \pm 5 \\
\mathrm{p}<0.001\end{array}$ & $\begin{array}{l}404 \pm 7 \\
p<0.01\end{array}$ & $\begin{array}{l}448 \pm 8 \\
p<0.05\end{array}$ & $\begin{array}{l}471 \pm 15 \\
\mathrm{p}<0.05\end{array}$ & $\begin{array}{l}497 \pm 14 \\
\mathrm{p}<0.05\end{array}$ \\
\hline $\begin{array}{l}\text { Trichloro- } \\
\text { ethylene }\end{array}$ & 2.0 & $375 \pm 4$ & $\begin{array}{l}380 \pm 5 \\
\mathrm{p}<0.001\end{array}$ & $\begin{array}{l}410 \pm 5 \\
\mathrm{p}<0.01\end{array}$ & $\begin{array}{l}449 \pm 6 \\
\mathrm{p}<0.05\end{array}$ & $\begin{array}{l}487 \pm 9 \\
p<0.05\end{array}$ & $\begin{array}{l}528 \pm 12 \\
0.2<\mathrm{p}\end{array}$ \\
\hline Distilled water & 2.0 & $375 \pm 1$ & $414 \pm 4$ & $438 \pm 7$ & $476 \pm 7$ & $512 \pm 7$ & $547 \pm 9$ \\
\hline
\end{tabular}

a Standard error of the mean. 
Table 3. Intraperitoneal toxicity after administration of 0.5 or $2.0 \mathrm{ml}$ of six solvents. Ten guinea pigs were used in each series.

\begin{tabular}{|c|c|c|c|c|c|c|c|c|c|}
\hline \multirow{2}{*}{ Solvent } & \multirow{2}{*}{$\begin{array}{l}\text { Injected } \\
\text { volume } \\
(\mathrm{ml})\end{array}$} & \multirow{2}{*}{$\begin{array}{c}\text { Mean } \\
\text { weight } \\
\pm \text { SEM a } \\
\text { (g) }\end{array}$} & \multicolumn{7}{|c|}{ Cumulative mortality rate } \\
\hline & & & $\begin{array}{c}\text { Hour } \\
1\end{array}$ & $\begin{array}{l}\text { Hour } \\
2\end{array}$ & $\begin{array}{c}\text { Hour } \\
3\end{array}$ & $\underset{6}{\text { Hour }}$ & $\begin{array}{l}\text { Hour } \\
24\end{array}$ & $\begin{array}{l}\text { Hour } \\
48\end{array}$ & $\begin{array}{l}\text { Hour } \\
72\end{array}$ \\
\hline $\begin{array}{l}\text { Carbontetra- } \\
\text { chloride }\end{array}$ & $\begin{array}{l}0.5 \\
2.0\end{array}$ & $\begin{array}{l}372 \pm 3 \\
373 \pm 6\end{array}$ & $\begin{array}{l}0 \\
0\end{array}$ & $\begin{array}{l}0 \\
2\end{array}$ & $\begin{array}{l}0 \\
5\end{array}$ & $\begin{array}{l}1 \\
8\end{array}$ & $\begin{array}{l}8 \\
9\end{array}$ & $\begin{array}{l}9 \\
9\end{array}$ & $\begin{array}{r}9 \\
10\end{array}$ \\
\hline $\begin{array}{l}\text { Dimethyl- } \\
\text { formamide }\end{array}$ & $\begin{array}{l}0.5 \\
2.0\end{array}$ & $\begin{array}{l}374 \pm 3 \\
374 \pm 6\end{array}$ & $\begin{array}{l}0 \\
0\end{array}$ & $\begin{array}{l}0 \\
0\end{array}$ & $\begin{array}{l}0 \\
0\end{array}$ & $\begin{array}{l}\mathbf{0} \\
\mathbf{3}\end{array}$ & $\begin{array}{l}\mathbf{0} \\
\mathbf{5}\end{array}$ & $\begin{array}{l}3 \\
9\end{array}$ & $\begin{array}{l}\mathbf{5} \\
\mathbf{9}\end{array}$ \\
\hline $\begin{array}{l}\text { Ethyleneglycol- } \\
\text { monobutylether }\end{array}$ & $\begin{array}{l}0.5 \\
2.0\end{array}$ & $\begin{array}{l}374 \pm 4 \\
374 \pm 8\end{array}$ & $\begin{array}{l}0 \\
7\end{array}$ & $\begin{array}{l}0 \\
9\end{array}$ & $\begin{array}{r}0 \\
10\end{array}$ & $\begin{array}{r}5 \\
10\end{array}$ & $\begin{array}{r}6 \\
10\end{array}$ & $\begin{array}{r}7 \\
10\end{array}$ & $\begin{array}{r}7 \\
10\end{array}$ \\
\hline n-Hexane & 2.0 & $372 \pm 2$ & 0 & 0 & 0 & 3 & 8 & 8 & 8 \\
\hline $\begin{array}{l}\text { 1,1,1-Trichloro- } \\
\text { ethane }\end{array}$ & 2.0 & $373 \pm 4$ & 1 & 8 & 8 & 8 & 8 & 8 & 8 \\
\hline $\begin{array}{l}\text { Trichloro- } \\
\text { ethylene }\end{array}$ & 2.0 & $373 \pm 5$ & 0 & 6 & 8 & 9 & 9 & 9 & 9 \\
\hline Distilled water & 2.0 & $375 \pm 9$ & 0 & 0 & 0 & 0 & 0 & 0 & $\mathbf{0}$ \\
\hline
\end{tabular}

a Standard error of the mean.

Table 4. Percutaneous toxicity of ten organic solvents.

Solvent

Applied volume

(ml)

No mortality, no effect on weight gain a

n-Hexane

No mortality, effect on weight gain

Benzene

Dimethylformamide

Ethyleneglycolmonobutylether

Toluene

1,1,1-Trichloroethane

2.0

Trichloroethylene

$5-25 \%$ of the animals died within 1 week

Carbontetrachloride

$0.5,2.0$

1,1,2-Trichloroethane

0.25

$30-75 \%$ of the animals died within 1 week

Dimethylformamide

2.0

Ethyleneglycolmonobutylether

1,1,2-Trichloroethane

2.0

$0.5,2.0$

$80-100 \%$ of the animals died within 1 week

2-Chloroethanol

$0.10,0.25,2.0$

a Distilled water $(2 \mathrm{ml})$ also belongs to this category.

\section{DISCUSSION}

Percutaneous toxicity can be defined as systemic poisoning following the penetration of toxic materials through the cutaneous barriers and their subsequent distribution throughout the whole body. The resulting toxic effect (i.e., mortality) thus depends both on the action of a substance on receptors ("inherent toxicity") and on the amount and rate at which it is absorbed from the application site (16).

n-Hexane caused no effect at percutaneous administration (tables 1,2 and 4 and fig. 1), while after intraperitoneal injection the number of mortalities was about the same as for dimethylformamide, 1,1,1-trichloroethane, and tricholorethylene.

In table 4 and fig. 2 and 3 , attempts were made to rank the 10 solvents studied to date, including benzene, toluene, and 1,1,2-trichloroethylene (17), and 2-chloroethanol (18). Five of the solvents $(2.0 \mathrm{ml})$ caused some mortalities (in declining order: 2-chloroethanol, 1,1,2-trichloroethane, ethyleneglycolmonobutylether, carbontetrachloride and dimethylformam- 


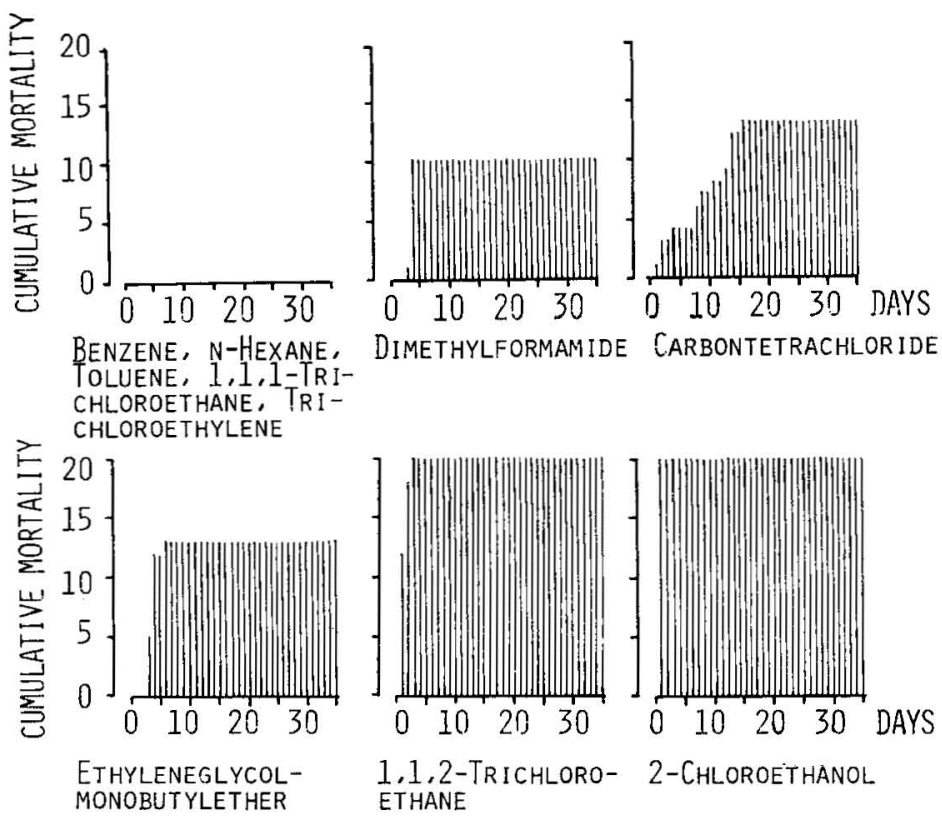

Fig. 2. Cumulative mortality after percutaneous solvent administration $(2.0 \mathrm{ml})$ of ten solvents. [Benzene, toluene and 1,1,2-trichloroethane values taken from Wahlberg (17); 2-chloroethanol values taken from Wahlberg \& Boman (18)]

ide). An effect on weight gain only was observed for the following four solvents: benzene, toluene, 1,1,1-trichloroethane and trichloroethylene.

The ranking list cannot be further evaluated, because no similar study has thus far been published. The acute dermal $\mathrm{LD}_{50}$ is $>9.4 \mathrm{ml} / \mathrm{kg}$ for carbontetrachloride and $0.23 \mathrm{ml} / \mathrm{kg}$ for ethyleneglycolmonobutylether (8), while we found that 13 of 20 animals died. Cutaneous application of dimethylformamide caused some mortalities in rats $(6,10)$ and "slight embryomortality" (12).

A comparison of percutaneous toxicity within the first week (table 4) and intraperitoneal toxicity within the first hours (table 5) shows fairly good agreement. There were two deviations that deserve comment however. Dimethylformamide $(2.0 \mathrm{ml})$ was number 4 on the list of percutaneous administrations, while the mortalities appeared comparatively late after the intraperitoneal injection. (Five animals died during the first $24 \mathrm{~h}$, and four more during $24-48 \mathrm{~h}$ ). In addition, after percutaneous administration, carbontetra-

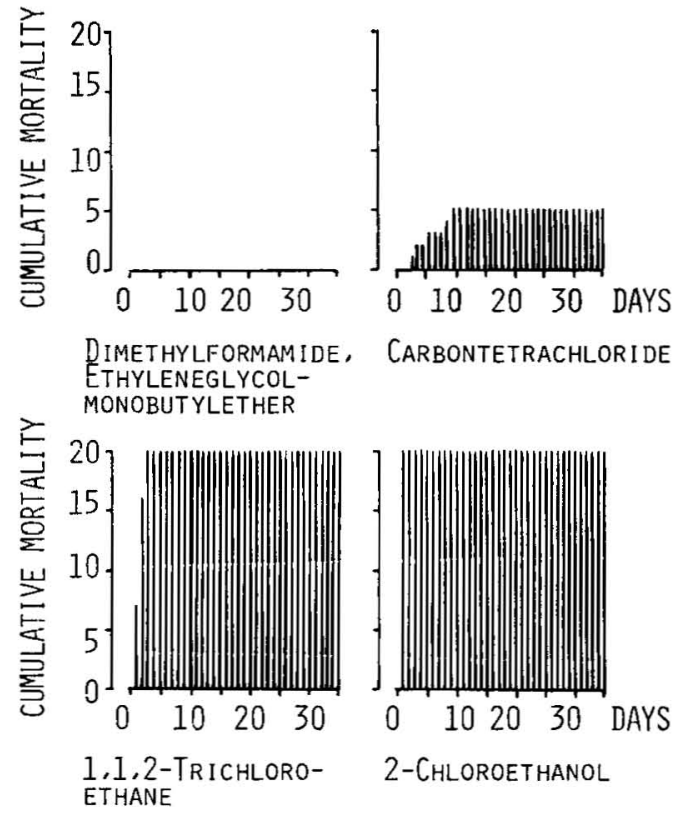

Fig. 3. Cumulative mortality after percutaneous solvent administration $(0.5 \mathrm{ml})$ of five solvents. [1,1,2-Trichloroethane values taken from Wahlberg (17); 2-chloroethanol $(0.25 \mathrm{ml})$ values taken from Wahlberg \& Boman (18)] 
Table 5. Intraperitoneal toxicity of ten organic solvents $(2.0 \mathrm{ml})$. Ten guinea pigs were used in each series.

\begin{tabular}{lcccccc}
\hline & \multicolumn{5}{c}{ Cumulative mortality rate } \\
\cline { 2 - 7 } Solvent & Hour 1 & Hour 2 & Hour 3 & Hour 6 & Hour 24 & Hour 72 \\
\hline 1,1,2-Trichloroethane & 9 & 9 & 9 & 10 & 10 & 10 \\
2-Chloroethanol & 8 & 9 & 10 & 10 & 10 & 10 \\
Ethyleneglycolmonobutylether & 7 & 9 & 10 & 10 & 10 & 10 \\
Toluene & 1 & 6 & 8 & 10 & 10 & 10 \\
1,1,1-Trichloroethane & 1 & 8 & 8 & 8 & 8 & 8 \\
Trichloroethylene & 0 & 6 & 8 & 9 & 9 & 9 \\
Benzene & 0 & 4 & 7 & 8 & 9 & 10 \\
Carbontetrachloride & 0 & 2 & 5 & 8 & 9 & 8 \\
n-Hexane & 0 & 0 & 0 & 3 & 5 & 9 \\
Dimethylformamide & 0 & 0 & 0 & 3 & 0 & 0 \\
\hline Distilled water & 0 & 0 & 0 & & 0 \\
\hline
\end{tabular}

chloride eventually caused the mortality of 13 of 20 animals (8 animals during the second week), while after intraperitoneal injection the mortalities also appeared comparatively late, the last animal dying between 48 and $72 \mathrm{~h}$.

The blood concentrations resulting from the administration of five of the solvents have been determined according to the same methodology as for 1,1,2-trichloroethane (3), and the findings will be presented in a forthcoming report.

\section{ACKNOWLEDGMENTS}

We are greatly indebted to Ms. M. Lagerstam-Bäckman for her excellent technical assistance.

\section{REFERENCES}

1. ENGSTRÖM, K., HUSMAN, K. and RIIHIMÄKI, V. Percutaneous absorption of $\mathrm{m}$-xylene in man. Int. arch. occup. environ. health 39 (1977) 181-189.

2. FUKABORI, S., NAKAAKI, K., YONEMOTO, J. and TADA, O. On the cutaneous absorption of 1,1,1-trichloroethane. J. sci. labour 53 (1977) 89-95.

3. JAKOBSON, I., HOLMBERG, B. and WAHLBERG, J. E. Variations in the blood concentrations of 1,1,2-trichloroethane by percutaneous absorption and other routes of administration in the guinea pig. Acta pharmacol. toxicol. 41 (1977) 497-506.

4. KRONEVI, T., WAHLBERG, J. and HOLMBERG, B. Morphological lesions in guinea pigs during skin exposure to 1,1,2trichloroethane. Acta pharmacol. toxicol. 41 (1977) 298-305.

5. KRONEVI, T., WAHLBERG, J. and HOLMBERG, B. Histopathology of skin, liver and kidney after epicutaneous administration of five industrial solvents to guinea pigs. Environ. res. 19 (1979) 56-69.

6. MASSMANN, V. W. Die arbeitshygienische beurteilung des dimethylformamids. Zentralbl. arbeitsmed. arbeitsschutz 6 (1956) $207-212$.

7. RIIHIMÄKI, V. and PFÄFFLI, P. Percutaneous absorption of solvent vapors in man. Scand. j. work environ. \& health 4 (1978) $73-85$.

8. ROUDABUSH, R. L., TERHAAR, C. J., FASSETT, D. W. and DZIUBA, S. P. Comparative acute effects of some chemicals on the skin of rabbits and guinea pigs. Toxicol. appl. pharmacol. 7 (1965) 559-565.

9. SATO, A. and NAKAJIMA, T. Differences following skin or inhalation exposure in the absorption and excretion kinetics of trichloroethylene and toluene. $\mathrm{Br}$. j. ind. med. 35 (1978) 43-49.

10. SCHOTTEK, W. Uber tierexperimentelle untersuchungen zur toxizität von dimethylformamid bei wiederholter einvirkung. Acta biol. med. ger. 25 (1970) 359-361.

11. STEWART, R. D. and DODD, H. C. Absorption of carbontetrachloride, trichloroethylene, tetrachloroethylene, methylene chloride and 1,1,1-trichloroethane through the human skin. Am. ind. hyg. assoc. j. 25 (1964) $439-446$.

12. STULA, E. F. and KRAUSS, W. C. Embryotoxicity in rats and rabbits from cutaneous application of amide type solvents and substituted ureas. Toxicol. appl. pharmacol. 41 (1977) 35-55.

13. TSURUTA, H. Percutaneous absorption of 
organic solvents: 1. A comparative study of the in vivo percutaneous absorption of chlorinated solvents in mice. Ind. health 13 (1975) 227-236.

14. WAHLBERG, J. E. Percutaneous toxicity of metal compounds. Arch. environ. health 11 (1965) 201-204.

15. WAHLBERG, J. E. A method for studying percutaneous toxicity of metal compounds in the guinea pig. Acta derm. venereol. 45 (1965) $171-177$.
16. WAHLBERG, J. E. Percutaneous absorption. Curr. probl. dermatol. 5 (1973) $1-36$.

17. WAHLBERG, J. E. Percutaneous toxicity of solvents: A comparative investigation in the guinea pig with benzene, toluene and 1,1,2-trichloroethane. Ann. occup. hyg. 19 (1976) 115-119.

18. WAHLBERG, J. E. and BOMAN, A. 2Chloroethanol - Percutaneous toxicity of a solvent. Dermatologica 156 (1978) 299302.

Received for publication: 21 May 1979 